\title{
Community Empowerment Model Based on Local Wisdom as An Effort to Reduce Maternal Mortality Rate in Jeneponto Regency
}

\author{
$1^{\text {st }}$ Yusriani \\ Faculty of Public Health \\ Universitas Muslim Indonesia \\ Makassar, Indonesia \\ yusriani83@ rocketmail.com
}

\author{
$2^{\text {nd }}$ Muhammad Khidri Alwi \\ Faculty of Public Health \\ Universitas Muslim Indonesia \\ Makassar, Indonesia \\ khidsri@yahoo.co.id
}

\begin{abstract}
The study was aimed to find a model of community empowerment based on local wisdom as an effort to reduce Maternal Mortality Rate (MMR). The research method was dominant-less dominant design. The result showed that the behavior of pregnant women in the effort to decrease the risk of MMR was a high risk. Community beliefs related to the health aspects of the mother were still strongly. Community participation was still lacking. Community Empowerment Model Based On Local Wisdom was triangle model PASALAMA.
\end{abstract}

Keywords - Community Empowerment, Local Wisdom, Maternal Mortality

\section{INTRODUCTION}

The maternal mortality component is closely related to the process of pregnancy, birth, postpartum. These three periods will determine the quality of human resources to come. Maternal mortality is an important component of demography to be examined because it plays an important role in the survival of a community group, whether it will develop, static or fail to survive.

Results of Indonesia Demographic and Health Survey (IDHS) in 2012 showed the maternal mortality rate reached 359 per 100 thousand births [1]. The number of maternal deaths in South Sulawesi in 2013 was 108 per 100,000 live births, and in 2014 it increased to 138 per 100,000 live births [2]. Trend The Maternal Mortality Rate in Jeneponto Regency also increased sharply from the year 2013 as many as 5 people ( 82 per 100,000 KH) to 13 deaths in 2014, 2015 with 11 deaths, and 8 deaths in 2016 [3].

A considerable increase in MMR is beyond expectations, quite a lot of interventions are being implemented by the Indonesian government. But has not produced maximum results, this is because Government policy is always oriented to the aspects of service, medical and only touch the aspects of social and economic determinants. In addition, due to the seriousness of the government has not been optimized. Government policy is always the policy of the program is top-down, partial, non-participatory and shortcuts. There has been no community-based intervention, conducted optimally and earnestly and directly touches the cultural aspects of society. So it is expected to reduce the MMR (Maternal
Mortality Rate). It needs to work harder to decrease the MMR beyond the current trend. It can no longer be a business as usual effort. Innovative efforts that have high leverage should be put forward in health development that is through the empowerment of society based on local wisdom by considering background characteristic, culture and ability of the society.

\section{MATERIALS AND METHOD}

The research method was dominant-less dominant design. In this study, the approach used as the main approach was quantified with survey descriptive to 189 pregnant women's by total population, while the qualitative approach was used as an alternative approach. The qualitative data on community participation in reducing maternal mortality was measured using interview guides, Focus Group Discussion guides and observation sheets.

This research will be carried out in the following stages:

1. Problems Identification. Conduct active meetings with community leaders, village heads, village leadership teams, health committees and other important people conducted in the community of intervening sites to discuss problem identification, prioritize problems and jointly to address maternal mortality issues.

2. Community Diagnosis. Conduct surveys of pregnant women, in-depth interviews and FGDs to explore information on mother's knowledge, attitude, practice/intentions. As well as digging information about community participation in preventing maternal death.

3. Analysis of Community Diagnostic Results. Have a meeting with the community to analyze the information they collected during the community diagnosis. Together with the community to find solutions/programs to overcome the problem, especially the prevention of maternal mortality.

4. Develop an alternative model of community empowerment based on local wisdom in an effort to reduce maternal mortality. 


\section{RESULTS AND DISCUSSION}

The process of identifying the problems in phase I obtained information about the condition of he location of the research that was a problem in an effort to reduce the risk of maternal death. Qualitative data obtained can explain and reinforce the findings of quantitative data. The problems identified are:

1. Low knowledge of pregnant women about efforts to reduce the risk of maternal death $(85.7 \%)$. Low knowledge was due to low education and lack of access to information. This is reinforced by the findings of qualitative data.

2. Negative community's belief in the concept of pregnancy care, childbirth and postpartum is still strong, among others: Still strong value charismatic central figure sanro or shaman in helping the process of pregnancy care, childbirth, and postnatal care. The belief in abstinence food, including foods of animal and vegetable classes is still strong.

3. Community customs relating to pregnancy, childbirth and postnatal had not been touched as a medium to increase knowledge of mothers, husbands and families about efforts to reduce the risk of maternal deaths.

Based on the results of data analysis, obtained information about knowledge, attitude, practice, maternal nutritional status as follows:

TABLE I. Knowledge, Attitude, Practice and Maternal Nutritional Status

\begin{tabular}{lrr}
\hline & \multicolumn{2}{c}{ Bontomate'ne } \\
\cline { 2 - 3 } Variabel & $\mathrm{N}=189$ & $\%$ \\
\hline Knowledge & 27 & 14.3 \\
$\quad$ Enough & 162 & 85.7 \\
Less & & \\
& & 70.9 \\
\hline Attitude & 134 & 29.1 \\
$\quad$ Positive & 55 & \\
$\quad$ Negative & & 3.2 \\
\hline Practice & 25 & 86.8 \\
$\quad$ Good & 164 & \\
$\quad$ Not Good & & 49.2 \\
& & 50.8
\end{tabular}

Phase II of community diagnosis used a qualitative approach,. This section describes community participation in reducing the risk of maternal mortality, priority issues, and finding alternative solutions to address the problem based on socio-cultural background and community capability by FGD method and observation. The community participation in reducing the risk of maternal mortality is still lacking.

Stage III The results of the joint diagnostic analysis of the community resulted in recommendations to address the priority of the problem of low knowledge, attitudes, and practice of based on local wisdom among others agreed that: 1. Problem solving by establishing PASALAMA' Community-Based Program Committee/local wisdom.

2. PASALAMA' Program Committee Based On Local Wisdom need to form PASALAMA' group with local term Pabburitta Kasalewangan Amma' (PASALAMA') IE People who deliver news/information about the mother's health by coming to the house of all relatives and all taiulan as an effort to decrease maternal mortality rate.

3. Training on PASALAMA' groups should be conducted in efforts to reduce maternal mortality by referring to local cultural beliefs that have been identified in stage I and will be expected to assist and promote health for pregnant women.

Stage IV and V resulted in a Local Wisdom-based community empowerment model in an effort to reduce maternal mortality, IE Triangle PASALAMA' model (Pabburitta Kasalewangang Amma') with "Empo Sipitangngari" Approach (Discussion).

The community empowerment model based on local wisdom in this research consists of planning, implementation and evaluation. The researcher puts himself/herself as a facilitator to provide information related to efforts to reduce maternal mortality in the study sites and to discuss for problem solving. While the community as the decision makers of each step of the activity and as a resource on the background of social culture and the ability of the community/local potential associated with the behavior of efforts to reduce maternal mortality. [4, 5, 6, 7, $8,9,10,11,12]$, that the growth and development of community participation in development will be pursued through the provision of opportunities based on the understanding that communities have traditional skills and wisdom and through intensive empowerment and sustainability.

The results of community diagnosis through FGD gave birth to an agreement to form a community-based PASALAMA program committee in an effort to reduce maternal mortality, FGD results also agreed that the PASALAMA program committee 'should form a group called local and based on the socio-cultural background of Pabburitta Kasalewangang Amma' (PASALAMA ') with Empo Sipitangngari approach/deliberation/negotiation through security triangle strategy. This local term was born 
to one of the FGD participants and agreed by the other participants.

Abbiritta in Makassar's cultural customs is delivering the news by going to the homes of all the relatives and all the friends as a form of appreciation to ask their willingness to attend an event or a party.

PASALAMA' is an abbreviation of Pabburitta Kasalewangang Amma' which comes from the Makassar language, which is a person who conveys information about maternal health in an effort to reduce the risk of maternal death. The process of delivering information to the individual, the family continuously and continuously follow the client's development, as well as the process of assisting the client, to change the client from not knowing was knowing or aware (knowledge or knowledge aspect), from know to be (attitude aspect or attitude) and from being able to perform the behaviors that are introduced (aspects of action or practice). Abbreviation PASALAMA 'in the Makassar language is a person who saves.

Empo Sipitangngari comes from the Makassar language which means Musyawarah. According to Big Indonesian Dictionary of Deliberation means discussion together with the intention to reach a decision on solving a joint problem or consensus. Mufakat means agreed. In the Decree of the Minister of Health (SK Menkes) no. 128/2004 on Puskesmas Basic Policy, it was explained that the meeting was attended by leaders (formal and informal) and community members to formulate the priority of health problem and the prevention effort

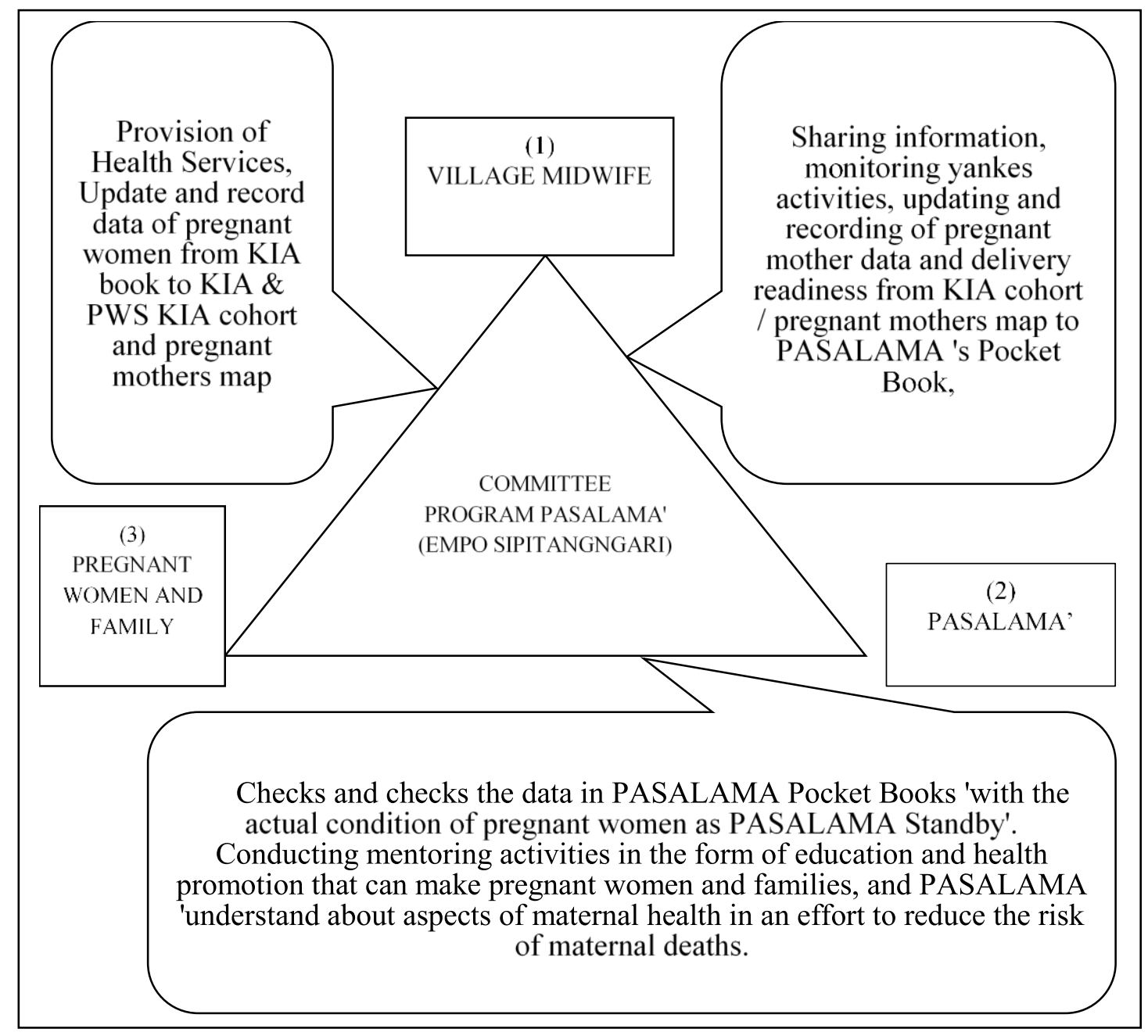

Fig 1. Security Triangle Strategy Through The Program Committee Approach "Empo Sipitangngari"

Program PASALAMA' Empo Sipitangngari approach is an empowerment effort, so that pregnant women and their families become subjects and not the object as happened so far. The Empo Sipitangngari approach uses consensus media to agree on preparedness to ensure maternal security from pregnancy, childbirth, to childbirth. While the interaction of each component in PASALAMA' program committee is a strategy to approach pregnant women to health services to improve their ability to help themselves (self care) in understanding that every pregnancy is risky. Empo Sipitangngari approach through PASALAMA' program refers to the strategy of the Ministry of Health of RI that is Moving and Empowering the Community for Healthy Life.

The security triangle is implemented holistically to ensure the safety of the mother from pregnancy to childbirth, using the empo sipitangngari approach between: 1) midwives in the village, 2) PASALAMA', and 3) pregnant women and their families in the program 
committee. It says holistic handling means for maternal health since pregnancy to childbirth is not only the responsibility of midwives in the village, but also pregnant women and their families and PASALAMA' with the approach of shrimp cultivation program committee through the security triangle. Holistic handling refers to the mission of the Ministry of Health RI is Making People Healthy.

Interaction between a pregnant mother and family with a midwife in the village is an activity of giving health service, update and record of pregnant mother data from KIA Book to KIA cohort and Local Area Monitoring KIA (PWS KIA) and map of the pregnant mother. The interaction between PASALAMA' and pregnant women is a check and data activity in Pasa Pocketbook' with the condition of actual pregnant mother as PASALAMA' alert, and conducting mentoring activity in the form of education and health promotion that can make pregnant mother and family, and PASALAMA' understand on aspects of maternal health in an effort to reduce the risk of maternal death. Interaction between village midwife and PASALAMA' that is, information sharing, monitoring of health service activity, update and record of pregnant mother data and readiness of delivery from KIA cohort/pregnant mothers map in PASALAMA' Pocket Book.

In depth interview explains that according to pregnant mothers for childbirth is the responsibility of the pregnant mother and family is not affairs of midwife in the village $[13,14]$.

The recommendations presented in the preliminary study are the implementation of the PASALAMA program consisting of maps of pregnant women, PASALAMA Pocket Books, Book of Recording and Reporting of PASALAMA and MCH Books [13, 14].

According to Budijanto and Sopacua (2006). the pattern of community empowerment is a strategic effort because it involves pregnant women as subject and not as object. It is explained that the map of pregnant women, Pocket Handbook of PASALAMA, Book of Recording and Reporting of PASALAMA 'and KIA Book interact with each other holistically through coordination to ensure the safety of pregnant women, childbirth until after childbirth. If pregnant women and their families understand the contents of the MCH Book, then this knowledge will have an impact on understanding the importance of delivery assistance of midwives in villages assisted by PASALAMA 'alertness. Coordination at village and hamlet levels is a technical implementation of Empo Sipitangngari Approach, which is translated as a consensus to agree.

The Empo Sipitangngari approach is facilitated by the Minister of Health Decree No.564/Menkes/SK/VIII/2006 on Guidelines for Implementation of Desa Siaga Development $[15,16,17]$.

Implementation is through the development of teams in the community as a form of community participation at the village level. Fostering community-level rural participation is a sequence, continuous and interrelated sequence of activities including village community forums, selfassessment (SMD) surveys, the village community meetings (MMD) and cadre training [15, 16, 17] through FMD socialization on alert villages is given to village apparatus, representatives from sub-districts, representatives from Puskesmas, community leaders and others.
The purpose of socialization so that community leaders are able to conduct SMD for their village with the guidance of health workers $[15,16,17]$.

The SMD data and findings are lists of health problems, potential data and community expectations, discussed in the MMD to determine the priorities, support and contributions that can be contributed by each individual/institution it represents and the solution steps in the development of Poskesdes and Desa Siaga $[15,16,17]$.

Planning of activities and funding required in the implementation of the PASALAMA' Program (the cost of transporting visits to work plots and the cost of organizing as needed in the interactive process) needs to be budgeted through the village fund allocation (ADD) and discussed jointly through the MMD approach.

The allocation of village funds (ADD) is a cash transfer that must be allocated by each district/municipality government to all villages of $10 \%$ of total balancing funds (general allocation funds and revenue-sharing funds) received by districts from the central government after deducting basic allocations for civil servant expenditures. This policy is stipulated in Law no. 32/2004 on Regional Government and PP. 72/2005 on Village, followed up by Minister of Home Affairs Letter to governors and regents/mayors throughout Indonesia. 140/640/SJ dated March 22, 2005 concerning Guidelines for Allocation of Village Funds from District/City Government to Village Government [15, 16, 17].

The Role of the Ministry of Health, especially the Directorate of Maternal Health and other relevant directorates as directors is urgently needed, as well as Provincial and District Health Offices. Steering or stewardship, according to WHO is a governmental function that is responsible for the welfare of the population, which relates to the trust and legitimacy of the population towards government activities, especially in the health sector [18]. One of the steering roles is to formulate and establish policies on the direction of health development, especially at the macro level.

Successful implementation of PASALAMA 'Program with Empo Sipitangari approach which is the acceleration strategy of decreasing maternal mortality rate need to be measured by determining indicator for input, process and outcome as a system [19, 20, 21, 22].

The expected impacts are the increase of $\mathrm{K} 1$ and $\mathrm{K} 4$ in ANC, delivered by health workers and referrals of pregnancy and maternal women on time prevented 3 late and maternal maternal deaths recording, delivery and postpartum were accurate. It all comes from good, organized, and comprehensive results because it involves all those involved in accelerating the reduced risk of maternal death $[23,24,25$, 26, 27, 28, 29, 30, 31, 32, 33].

\section{CONCLUSION}

A Community empowerment model based on local wisdom in an effort to reduce maternal mortality is model triangle PASALAMA' (Pabburitta Kasalewangang Amma') with Approach "Empo Sipitangngari" (Discussion). Need to apply Local Wisdom-Based Community Empowerment Model in an effort to reduce maternal mortality rate to build maternal health knowledge and experience related to maternal health. 


\section{ACKNOWLEDGMENT}

We would like to thank all the respondents of this research in Jeneponto district, especially to the local government of Jeneponto in supporting this research. The author(s) fully thanks to the Minister of Research and Technology, Higher Education for the financial support for the research, authorship, and/or publication of this article by the name of Doctoral Research Grant Funding. The author(s) declared no potential conflicts of interest with respect to the research, authorship, and/or publication of this article.

\section{REFERENCES}

[1] WHO and WORLDBANK, 'Trends in Maternal Mortality: 1990 to 2010', Organization, 32(5), pp. 1-55. doi: ISBN 978924150363 1, 2012.

[2] Ansariadi, "Epidemiology of maternal mortality rate in Sulawesi Selatan 2008-2013: what has been changed?", 2015.

[3] Dinkes, "Health profile of Jeneponto district", Dinkes Jeneponto, 2017.

[4] Afiyah, "Banned food for pregnancy", Universitas Diponogoro Semarang, 2002.

[5] Alwi, Q, "Potential factors influencing the maternal mortality rates in Palembang and Mura district", Media Litbang Kesehatan, pp. 7$15,2006$.

[6] A. Nurhaeni, "Healthy pregnancy and birth", Yogyakarta, Dian Loka, 2008.

[7] Astriana, "Childbirth process in Galang village Sungai Pinyuh district Pontianak", Sociedev: Journal S-I Ilmu Sosiatri. Ilmu Sosiatri Fisip Untan, Volume I(1), 2012.

[8] Yusriani, 'Nutritional Status and Health Behavior of Pregnant Women in Phc of Bululoe, Jeneponto District', Dama International Journal of Researchers Available @ www.damaacademia.com Dama International Journal of Researchers, 878(8), pp. 2343-6743, 2016.

[9] Yusriani et al, 'Socio-Cultural Role in Practice Antenatal Care, Delivery Process and Postnatal Care (Studies in Turatea Sub District Jeneponto District)', Dama International Journal of Researchers (DIJR), 1(10), pp. 26-32, 2016.

[10] Yusriani, 'Survey of Nutritional Status and Health Behavior of Pregnant Women in Bontomate'Ne Health Center of Jeneponto District, Indonesia', Public Health of Indonesia, 22(2), pp. 55-67. Available at: http://stikbar.org/ycabpublisher/index.php/PHI/index, 2016.

[11] Yusriani et al, 'Health Social Determinant to Maternal Mortality Risk in PHC of Bululoe, Jeneponto District', Dama International Journal of Researchers (DIJR), 2(7), pp. 1-6, 2017.

[12] Zhao Q, K. A., GAO Y, XU B, Knowledge and attitude on maternal health care among rural-to-urban migrant women in Shang Shanghai, China. . BMC Women's Health 9, 5, 2009.

[13] Prajoga, Sopacua E, Budijanto D, "Integrated patterns: working system evaluation", Research and development center of health department of East Java, Surabaya, 2005.

[14] Sopacua E, Budijanto D, Prajoga., "Problem identification to optimalize the work of health department and primary health care through safe motherhood kalakarya activity", Research and development center of health department of East Java, Surabaya, 2003.

[15] Health department of Republic of Indonesia, Decision of Ministry of Health Number. 546/MENKES/SK/VIII/2006 about guidance to build standby village Jakarta, 2006.

[16] Health department of Republic of Indonesia, guidance to build standby village, First Modul, Jakarta, 2006

[17] Health department of Republic of Indonesia, Guidance to build relationship in society, Second Modul, Jakarta, 2006.

[18] World Health Organization, WHO Report, Geneva, 2000.

[19] Budijanto D, Sopacua E, Prajoga, "Guidance for pregnant mothers by midwife", Research and development center of health department of East Java, Surabaya, 2004.

[20] Budijanto D, Sopacua E, "Strategic triangle: a pattern of public-private partnership in decreasing maternal mortality rates", Symposium 3, Research and development department 1 - 2 December, Jakarta, 2006.

[21] Butawa NN, T. B., Idris H, Adiri F, Taylor KD, Knowledge and perceptions of maternal health in Kaduna state, northern Nigeria, Afr J Reprod Health 14, 71-76, 2010.

[22] Center For Research On Environment Health And Population Activities (CREHPA), The influence of male partners in pregnancy decision- making and outcomes in Nepal. Seattle: Program for Appropriate Technology in Health (PATH), 2007.

[23] Horstman RG, N. B., Dev Pant P, Husband involvement in the prevention of maternal ill-health: the determinants of husband domestic support in rural low-land Nepal. . Princeton: Princeton University. [Cited 2011 Jun 16]. Available from: URL: http://paa2004.princeton.edu/ download.asp?submissionld $=40758$, 2004.

[24] Kistiana, Socio-economic and demographic determinants of maternal health care utilization in Indonesia. Adelaide: The Flinders University of South Australia, 99 pp. Master's dissertation, 2009.

[25] Manandhar M, Obstetric health perspectives of Magar and Tharu communities: A soscial research report to inform the Nepal Safer Motherhood Project's IEC strategy. Kathmandu: Family Health Division, 2000.

[26] Mahmudah, "Mothers knowledge of pregnancy risks", Tuban, 2011.

[27] Morgan SP, N. B, Gender inequality and fertility in two Nepali villages. Popul Dev Rev 21: 541-61, 1995.

[28] M. Sri, "Influencing factors of pregnant mothers", Thesis, Universitas Indonesia, 2009.

[29] Yousif Mohamed, 'The Effect of Antenatal Care on the Probability of Neonatal Survival at Birth, Wad Medani Teaching Hospital', Sudan Journal of Public Health, 1(4), 2006.

[30] Devy s. et al, "Pregnancy care in madura culture in Tambak and Rapalaok village Sampang district", Journal of Health Promotion of Faculty of Public Health Universitas Airlangga, Vol 1, No.1, Maret 50-62, 2011.

[31] Raghupathy S, Education and the use of maternal health care in Thailand. Soc Sci Med. 43: 459-71, 1996.

[32] Sharma A. Male, Involvement in reproductive health: Women's perspective. J Fam Welfare Vol 49, 1-9. 2003.

[33] Bloom SS, T. A., PLOTKIN M, BASSET S, What husbands in northern India know about reproductive health: Correlates of knowledge about pregnancy and maternal and sexual health. $J$ Biosoc Sci, 32: 237-51, 2000. 